WEP 2-26/WP. 3

WORLD EMPLOYMENT PROGRAMME

Working Paper

MIGRATION FOR ENIPLOYMENT PROJECT

INTERNATIONAL MIGRATION

IN SOUTHERN AFRICA

by

Francis Wilson

Note: Working Papers are preliminary material circulated to stimulate discussion and critical comment

Copyright (C) International Labour office

Geneva,November 1975 
TABLE OF CONTENTS

Page

A. FOREWORD, by W. R. Böhning ................. 1

B. INTERNATIONAL MIGRATION IN SOUTHERN AFRICA, bY

F. Wilson ............................

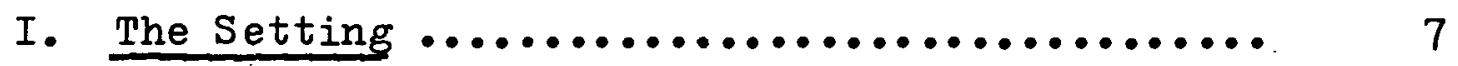

II. The Background $\ldots \ldots \ldots \ldots \ldots \ldots \ldots \ldots \ldots \ldots \ldots \ldots$

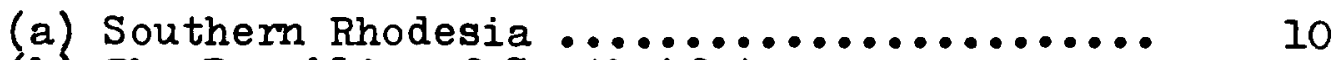

(b) The Republic of South Africa ............ 12

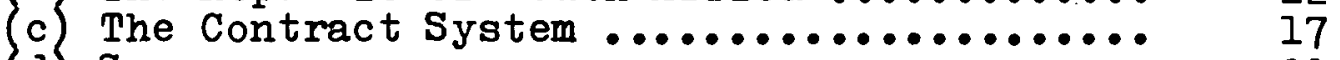

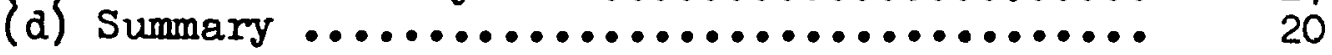

III. The Impact of Immigration ................ 22

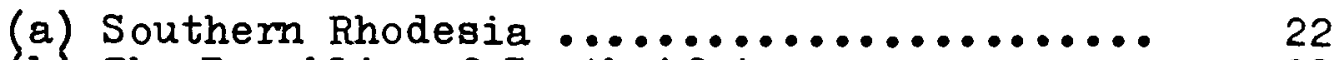

(b) The Republic of South Africa ............ 23

(c) The Present and the Future in the Mining

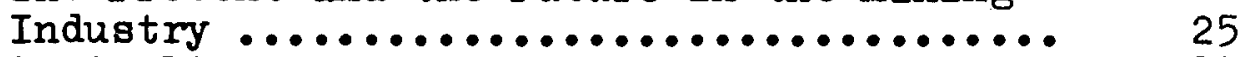

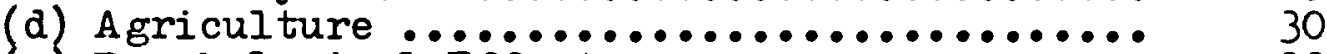

(e) Psychological Effects ................ 33

(f) Labour Control ...................... 34

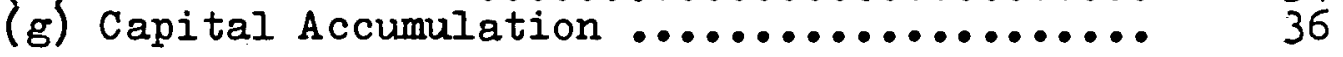

IV. The Impact of Emigration ............... 37

(a) Short-run Benefits: Individuals and Remittances .......................... 38

(b) Short-run Costs: Agriculture and Income

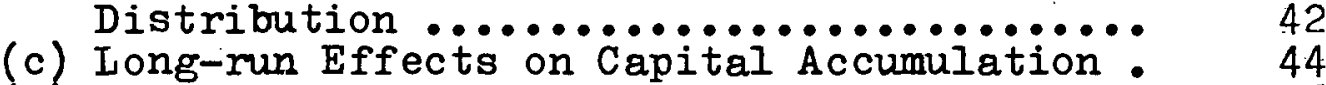

(d) Summary ......................... 46

V. Conclusion: Reducing the Dependence of Emigration

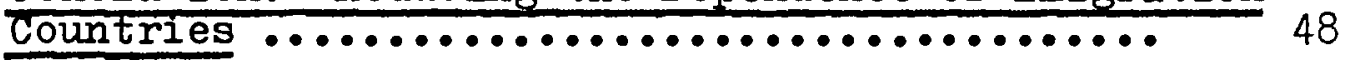

(a) Industrial Decentralisation ............. 49

(b) Correcting One-sided Capital Accumulation 52

(c) A reas of Negotiation .................. 54

(d) The Future of Migration for Employment ... 56 


\section{A. FOREWORD}

During the preparations for next June's Tripartite World Conference on Employment, Income Distribution and Social Progress and the International Division of Labour a number of studies were commissioned to shed light on agenda items that could not be covered adequately at ILO Headquarters. "International manpower movements and employment" is one of the agenda items. ${ }^{1}$ And Francis Wilson's paper is one of those studies.

The author faced a pioneer's task. He was asked to examine not only the immigration scene in the Republic of South Africa but also the black emigration countries surrounding this white citadel. What effects does the outflow of Basotho, Batswana etc. have on the home countries; how do these labour movements influence the economic relationships between sending and receiving countries; what prospects, if any, are there for substituting trade for labour flows; what does the future hold; and what policy lessons are to be draw from the analysis? Practically nothing has been said or written about these questions. The author acquitted himself excellently in the very few weeks at his disposal. (The manuscript is dated June 1975).

This is one of the contributions that could not be included in the forthcoming volume of background papers for the World Conference on Employment, mainly because of its nature as a case study as opposed to a global survey. In view of its quality

\section{The others are:}

- national employment strategies and policies with particular reference to developing countries

- active manpower policies and adjustment assistance in developed countries

- the role of multinational enterprises in employment creation in developing countries

- technologies for productive employment creation in developing countries. 
and the information contained in it we were anxious to make the paper available to a wider readership. The fulllength version is therefore issued in this Working Paper and a greatly reduced version is scheduled for publication in the International Labour Review some time next year.

It may be of interest to readers to know that the Migration for Employment Project will carry the investigation of migration in the Southern African region further with a policy-oriented study supported by the United Nations Fund for Population Activities. Its objectives are as follows:

\section{A. L̇ongrange Objectives}

The principal long-term objective is to provide a satisfactory knowledge base for an assessment of the desirability of out-migration from actual or potential supplier countries such as:

- Botswana, Lesotho and Swaziland

- Malawi

- Angola and Mozambique as newly independent countries;

- and the special case of Namibia.

This assessment should be based on an evaluation of the economic, social and demographic pros and cons of substantial out-migration for the migrants involved (micro level) and their home countries at large (macro level), differentiating by short-term and long-term effects and by the various skill levels involved ("brain drain", "skill drain", unskilled workers).

If such an assessment is to be viable, it is necessary to explore the policy altematives open to emigration countries, i.e. the option of having no emigration. In Southerm Africa, President Banda's decision to suspend the recruitment of Malawians pending an investigation into the causes of the crash of an aircraft in Botswana in April 1974, which killed 72 Malawian miners, provides empirical material for a detailed and hard-headed examination of foregoing the emigration option. 
Should the assessment point to the desirability of emigration, the project should specify the exact form that would:

(a) give optimal results from the viewpoint of the home country,

(b) be feasible in terms of domestic implementation, and

(c) be negotiable with the given demanders of manpower.

As a working hypothesis, it should be the goal of any such system of planned migration:

(i) to make the home country decreasingly dependent upon the export of labour;

(ii) to improve the terms on which this movement takes place, both in narrow economic terms (working conditions) and in broader social welfare terms (living conditions);

(iii) to minimise possible detrimental effects of emigration such as:

- neglect of animal husbandry and agriculture

- brain drain and/or skill drain

- output losses in the modern sector

- wage pressure in skilled or highly skilled grades

- income distribution against non-migrants, and

- disaccumulation of capital in the sense that the tax revenue associated with the engagement of foreigners accrues wholly to the country of employment; $^{1}$

1 Cf. Wilson's treatment, below. 
(iv) to maximise potential benefits that could derive from a well planned migration system such as:

- relief of unemployment and underemployment

- increased transfer of earnings and savings

- more productive use of earnings and savings

- return of manpower initiated to commercial farming or industrial working habits and possibly endowed with useful skills;

Furthermore, the possibilities should be explored for a common approach and joint action by supplier countries vis-à-vis individual or grouped employment countries in matters of:

- information

- prospection of labour surpluses and. establishment of individual countries' shares in total flows

- negotiations with employment countries on both actual migration flows and working and living conditions of migrants, including questions of social security.

\section{B. IMMEDIATE OBJECTIVES}

The first and basic question of the project, and therefore its most immediate objective, is the establishment of the likely volume and characteristics of the demand for labour arising over the next 5,10 and 15 years in the Republic of South Africa.

The next immediate objective is to undertake complementary studies for the supply of labour in the respective emigration countries covering the same period, 1975-1990.

Any evaluation of the effects and the pros and cons of emigration (and, incidentally, of immigration) is basically determined by the scale of both gross and net flows and how these flows are composed. The evaluation proposed and outlined in the preceding section (and which, though performed as an integral second step of the project, can only be implemented over a number of years and in this sense constitutes a longrange objective) must be based on the best available estimates 
of future demand for labour in order to be of practical significance. A brief look at some of the issues of such a forecasting exercise will show that the question is by no means as simple and straightforward as it appears at first glance.

Future supply of manpower is determined not only by demographic, socio-economic and education-cum-training factors, but also by the rate of white immigration and the internal policy of the country towards its black population. The demand side has to be disaggregated into farming, mine development, manufacturing and city services, and examined for the implications of (i) the planned-for mechanisation of mining, ( $i i)$ the wage push, and (iii) the likely shift of the colour bar. The 1973-74 compound confrontations, the Malawi aircrash and the subsequent walk offs are partly responsible for all three factors. But they also have the effect of making South African employers wary of their dependence on migrant labour.

A necessary complementary study would have to look at the supplier countries, their demographic and economic development, and the quantitative and qualitative imbalances in jobs and manpower.

\section{Institutional Framework}

The project will be subcontracted to the University of Botswana, Lesotho and Swaziland but not to any institution in the Republic of South Africa. 


\section{B. INTERNATIONAL MIGRATION \\ IN SOUTHERN AFRICA}

by

Francis Wilson

(Southern Africa Labour and Development Research Unit, School of Economics, University of Cape Town) 
I. The Setting

The migration of workers in response to political and economic pressures is no new thing in Southern Africa. The movement of people to, from, or within the sub-continent whether as colonists, slaves, refugees, indentured labourers, immigrants, or oscillating migrants is one of the most arresting features of our history. Analysis of the flows of labour (and capital) is an essential part of the process of understanding the nature of the social, economic, and ecological imbalances so manifest in Southern Africa. Vital though the broader perspective is we shall not attempt to cover all the ground. We shall not go back very far in time; we shall not examine the implications of the flow of capital investment to particular areas of the sub-continent especially from Western Europe and the United States; we shall not analyse the political and economic consequences of the migration of whites to Southern Rhodesia and to the Republic of South Africa in recent years. In passing we would simply note that over the years 1955 to 1974 Southern Rhodesia's total net inflow of 51,000 whites was less than South Africa's net white immigration in any two years between 1963 and 1972. Over the period 1924 to 1974 South Africa's net gain of white immigrants was almost exactly half a million people. ${ }^{2}$ Nor shall we consider the

1 I am grateful to many people for discussion and criticism which over the years has helped to mould my own thinking as expressed in this paper. In particular I wish to thank Wolfgang Thomas and the various members of a joint anthropology-economics seminar group on international migration for their critiques of an early draft. 2 Central Statistical Office, Monthly Digest of Statistics (Salisbury, January 1975) and Republic of South Africa, Dept. of Statistics, Migration Statistics: Tourists Immigrants and Emigrants 1970 and 1971 (Report No. 19-01-02, Pretoria).

The South African figures are for all races but exclude oscillating migrants. From the regional breakdown it is safe to assume that the majority of immigrants referred to in these figures are white. Sae also White Migration to Southerm Africa (Centre Europe - Tiers Monde, Geneva, 1975). 
ebb and flow of workers within the boundaries of South Africa in whose major urban areas it is estimated that approximately one out of every two black men legally at work is housed as a migrant on a single basis. 1 our brief is to focus on the single aspect of the intermational flow of migrant workers and its consequences over the past twenty five years. In so doing we would stress that this paper cannot be seen in isolation from those other dimensions to which we have referred, but if one is to dig deep one must limit oneself and start somewhere.

In the context of Southern Africa the term 'migrant' tends to be defined as meaning a worker who oscillates between his home and his place of work over a distance which is greater than can be travelled on a daily commuting basis. In terms of this definition migrants, always black in Southem Africa, may be workers who live either inside or outside the borders of the Republic of South Africa, (or Southern Rhodesia) but who, either way, are living at work without their families. On the gold mines of the Witwatersrand and the Orange Free state, for example, virtually all (99 per cent) of the 380,000 or so black workers employed during the first half of the 1970's were housed as single men in hostels or compounds each holding between 1,000 and 8,000 persons who came both from within the Republic of South Africa as well as from countries further afield ${ }^{2}$ From many employers' points of view there is little difference between workers whether they come from Lesotho or from the Ciskei, but for the purposes of this paper we shall be considering only those migrants whose homes are across international boundaries. Once

1 Francis Wilson, Migrant Labour in South Africa. South African Council of Churches and Spro-cas, Johannesburg, i972) pp.29-77.

2 The sizes of compounds refer to those of one mining group. Ibid. p.10. 
one starts looking only at the intemational flows one must also take into account the movements of people for longer than the conventional contract periods of the oscillating migrants. In South Africa, in Southerm Rhodesia, and in Zambia there has, over the years, been a certain amount of more permanent migration of foreign-borm Africans moving in and settling. Nevertheless the most striking feature of the international migration within the African sub-continent is the extent to which it has been, and still is, of an oscillating nonpermanent nature.

\section{The Background}

The origins of the modern system of migrant labour go back to the mineral discoveries in the latter half of the 19th century. The closed compounds in Kimberley built to prevent illicit diamond buying, and the compounds erected on the Witwatersrand to house indentured Chinese brought in to mine gold set the pattern for the decades that followed. Both the Native Recruiting Corporation and the Witwatersrand Native Labour Association were established by the Transvaal Chamber of Mines before the First World War. Recruiting was never confined to the borders of South Africa: before the turn of the century some 60 per cent of the men working on the Witwatersrand gold mines came from Mozambique. And in the same decade Leso tho had 30,000 men working on the South African mines and railways. Large numbers have also come from there for many years to work on the farms, particularly in the Orange Free State.

This historic perspective highlights the fact that the current flows of foreign workers into South Africa are, despite important similarities, significant different from the migrant patterns in Western Europe with which they are often compared. The main difference lies in the fact that the movements of, for example, Turks to Germany or Algerians to France is essentially something that has grown up since the Second World War. In 
Southern Africa, by contrast, the oscillating migrations go back to before the First World War as regards movements from Mozambique, Botswana, Lesotho, Swaziland, and Malawi. ${ }^{1} \mathrm{~A}$ crucial aspect of economic growth in Southern Africa is that although it has taken place primarily within the Republic of South Africa and Southerm Rhodesia it has always drawn on 'temporary' labour from far beyond the national boundaries. It is impossible to analyse the economic development, during the past century, of any country in Southern Africa as though it was a self-contained unit. ${ }^{2}$

\section{(a) Southern Rhodesia}

Focussing on Southern Rhodesia for a moment we find that the first formal arrangements for migrant workers go back to 1903 when the Rhodesian Native Labour Bureau was set up to coordinate recruiting of foreign labour for mines and plantations. In 1927 a free transport service, administered by the government of Southerm Rhodesia, was established to bring recruits for a minimum of twelve months from Malawi (then Nyasaland) to work on mines and farms. ${ }^{3}$ By 1954 (the first year for which detailed figures are available) the average flow of foreign African men into and out of the country was over 100,000. Forty-six per cent

1 In 1913, because of the Pneumonia death rate, South Africa prohibited recruiting north of latitude $22^{\circ} \mathrm{S}$. (just north of Beit Bridge). With medical development recruitment was resumed 20 years later. There was no such hiatus in labour flows from Malawi to Southern Rhodesia which itself lies within the tropical zone.

2 Four recent writers who make this point particularly forcefully are Roger Leys, 'Iesotho: Non-Development or Under-Development?' (mimeo I.D.R. Project Paper, Copenhagen, 1973). Archie Mafeje "The Fallacy of "Dual Economies" Revisited - a case for East, Central and South Africa' (mimeo Institute of Social Studies, The Hague, 1973). Percy Selwyn, 'Industrial Development in Peripheral Small Countries' (I.D.S. Discussion Paper No.14, Brighton, 1973). Duncan Clarke, Contract Workers and Underdevelopment in Rhodesia (Mambo Press, Gwelo, 1974).

3 clarke op.cit. p. 8 and W. J. Breytenbach, Migratory Labour Arrangements in Southerm Africa (Africa Institute, Pretoria, 1972) p.61. 
were bom in Mozambique, 36 per cent in Malawi, 12 per cent in Zambia, and the remaining 6 per cent elsewhere. Since then, however, as the following table makes clear, there has been a dramatic decline in the annual flow of workers.

TABLE 1

Southerm Rhodesia: Migrant Flows ${ }^{(1)} 1954$ - 1974 (Black Males) Country of Origin

\begin{tabular}{|c|c|c|c|c|c|c|c|c|c|}
\hline \multirow[t]{2}{*}{ Date } & \multicolumn{2}{|c|}{ Malawi } & \multicolumn{2}{|c|}{ Mozambique } & \multicolumn{2}{|c|}{ Zambia } & Other & \multicolumn{2}{|l|}{ Total } \\
\hline & $\begin{array}{c}\text { Flow } \\
(\text { OOOS })\end{array}$ & $\begin{array}{l}\text { Im: } \\
\text { Em* } \\
\%\end{array}$ & $\begin{array}{c}\text { Flow } \\
\text { (000s) }\end{array}$ & $\begin{array}{l}\mathrm{Im}: \\
\mathrm{Em} \cdot * \\
\%\end{array}$ & $\begin{array}{l}\text { Flow } \\
\text { (000s) }\end{array}$ & $\begin{array}{l}\text { Im: } \\
\text { Em.* } \\
\%\end{array}$ & $\begin{array}{c}\text { Flnw } \\
(000 \mathrm{~s})\end{array}$ & $\begin{array}{l}\text { Flow } \\
\text { (OOOs) }\end{array}$ & $\begin{array}{l}\text { Im: } \\
\text { Em. } \\
\%\end{array}$ \\
\hline 1954 & 37,7 & 128 & 48,3 & 110 & 13,2 & 74 & 6,6 & 105,8 & 110 \\
\hline 1959 & 42,7 & 84 & 37,9 & 85 & 8,6 & 130 & 3,1 & 92,3 & 87 \\
\hline 1964 & 25,9 & 101 & 10,1 & 80 & 6,8 & 33 & 1,7 & 44,5 & 83 \\
\hline 1969 & 9,4 & 115 & 6,1 & 84 & 1,4 & 9 & 0,1 & 17,0 & 88 \\
\hline 1974 & 3,9 & 78 & 2,2 & 289 & 0,5 & 29 & 0,1 & 6,7 & 108 \\
\hline
\end{tabular}

Source: Central Statistical Office Monthly Digest of Statistics (Salisbury, February, 1975).

Notes: (1) 'Flow' is the average number of persons moving in and out. i.e. Flow = (Immigrants + Emigrants) $: 2$

* This percentage gives some idea of the extent of oscillation. In 1954, for instance, 128 Malawians entered Southerm Rhodesia for every 100 who left. In 1955 for every 100 Malawians who left only 84 entered Southern Rhodesia; etc.

In terms of legislation passed in 1946 a male migrant labourer who was the head of a family could not be absent from home for a period exceeding 2 years. ${ }^{1}$ During the years of the

1 Much of the information in this paragraph is taken from Breytenbach op. cit. chapter 7 and Clarke op. cit. pp.91 ff to which the reader is referred for details. There are discrepancies in the official statistics some of which suggest a net outflow and others a net inflow of foreign workers over the period 195474. Part of the difficulty as W.J. Breytenbach points out (personal communication with the author) is the lack of uniformity as far as definitions of foreign workers are concemed. Another possibility is that inflow counts may be less accurate than outflow counts or vice versa. 
Central African Federation (1953 to 1963) Malawians coming to work in Southern Rhodesian agriculture were all allowed to bring their families with them, whilst other Malawian and Zambian recruits were allowed to settle after their first 24 month period of service. In this period it is estimated that some 150,000 Malawians and Zambians were absorbed into the Federation. However in 1965/6 Zambia banned the emigration of workers to Southern Rhodesia which itself was introducing controls to reduce the number of foreign workers. The first of these controls was introduced in 1958 with the introduction of the Foreign Migratory Labour Act which gave the government the power to restrict non-Federal Africans from employment in 'closed labour areas'. An example of its impact was the Closed Labour Areas Order of 1966 in terms of which non-Rhodesian blacks have been prohibited from employment within a ten mile radius of the major urban centres unless they obtain special permission. At the same time 'free flow' migrants from Malawi were restricted to the eastern agricultural districts of the country. ${ }^{1}$ Thus over the period 1954 to 1974 the average annual flow of foreign migrants fell drastically from 106,000 to under 7,000 men. Nevertheless foreign-born workers, most of them now more permanently settled, remain a significant proportion of the Southern Rhodesian labour force, particularly in agriculture.

(b) The Republic of South Africa

In South Africa the unfolding pattern of labour migration has been quite different. Whereas Southerm Rhodesia's dependence on foreign black migrant workers has fallen dramatically since the early 1950's that of South Africa has continued to increase. Indeed, as can be seen from the following table, the dependence of the South African mining industry upon foreign workers at the beginning of the 1970's was higher than it had been since the turn of the century when Chinese labourers were indentured to replace local Africans.

1 of the 69,000 Malawians registered as entering Southern Rhodesia over the period 1965-69, 51,000 (73 per cent) of them were 'free flow' migrants: i.e. people not having specific contracts of service. Unlike in South Africa these workers are compelled by law to remit family allowances and deferred pay. 


\section{TABLE 2}

Geographical Sources of African Labour Employed ${ }^{(1)}$ by Mines affiliated to the S.A. Chamber of Mines (2), 1906-1974

$\frac{1906}{(000 s) \%} \quad \frac{1936}{(000 s) \%} \quad \frac{1946}{(000 s) \%} \quad \frac{1960}{(000 s) \%} \frac{1970}{(000 s) \%} \frac{1973}{(000 s) \%} \frac{1974}{(000 s) \%}$

South Africa

Lesotho

Botswana

Swaziland

Mozambique

North of
Lat. $22^{\mathrm{O}} \mathrm{S}$.

Total
$18 \quad 22,8$

$2 \quad 2,6$

$0,3 \quad 0,4$

$0,6 \quad 0,7$

5365,4

68,0

$81 \quad 100$
16652,2

4614,5

72,3

72,2

8827,8

31,1

318100
12641,3145

3812,5

$51 \quad 130717,7$

8620,492

25,2

$\begin{array}{llllllllllll}7 & 2,3 & 16 & 4,0 & 16 & 4,0 & 17 & 4,0 & 15 & 4,1\end{array}$

$\begin{array}{llllllllll}6 & 1,8 & 6 & 1,4 & 5 & 1,3 & 5 & 1,1 & 5 & 1,4\end{array}$

9631,5

$9524,111328,29923,6102$

27,9

3210,6

$8320,99824,512830,3 \quad 73$

20,0

\section{Total}

\section{0}

\section{$397 \quad 100401100 \quad 422100 \quad 365100$}

Sources: W.N.L.A. Annual Reports.

Notes: (1) As at 3lst December

(2) In $193615,000(4,7 \%)$ of the totel were in coal mines of the Transval, the rest in gold mines. By 1970 the number was 34,000 ( 8,4 per cent). Details of black workers in most other mines (e.g. Platinum, Copper, Natal collieries, etc.) are not available.

In 1946 there were, according to the official census, 556,000 foreign-borm Africans in South Africa. ${ }^{1}$ One-fifth $(111,000)$ were women. Of the 445,000 males 40 per cent $(179,000)$ were employed on gold and coal mines affiliated to the Chamber of Mines. In 1954 the number of foreign Africans working on these mines alone had risen to 208,000, almost twice the number of foreign Africans in the economy of the Central African Federation at that time. By 1964 the number of foreign workers, excluding those on most of the farms, had risen to 352,000. Of these 231,000 (66 per cent) were employed in the gold mines 21,000 ( 6 per cent) in coal mines of the Transvaal and 42,000 (12 per cent) in mines not affiliated to the Chamber. 2

$1 \mathrm{~J} . \mathrm{I}$. Sadie, Projections of the South African population (Industrial Development Corporation, Johannesburg, 1973) p. 26. 2 G.M.E. Leistner, 'Foreign Bantu Workers in South Africa: Their Present Position in the Economy' S.A.J.E., March 1967,p.48. 
The number of foreign migrants working on South African farms is not known precisely but it is common cause that there have been substantial 'free flows' and clandestine migrations over the years from limitrophe countries, especially from Lesotho into parts of the Orange Free State and Natal, from Mozambique into the eastern Transvaal lowveld and northerm Natal, from Southern Rhodesia into the northerm Transvaal, and from Botswana into the maize triangle. However during the 1960 's the South African government began to tighten up control of these free flows. Prior to 1963 Africans from the 'High Commission Territories' (now Botswana, Iesotho and Swaziland) did not require passports to enter South Africa although they were, like other Africans, compelled to carry reference books. With the introduction of migrant labour control measures which differentiated South African from foreign Africans the flow of unchecked clandestine immigrants, reports Breytenbach, "was drastically curtailed"I. The impact of South Africa's declared policy of reducing the number of foreign Blacks as fast as is feasible' in practice ${ }^{2}$ may be seen in the fact that over the period 1960-1970 the number of persons from Botswana, Iesotho and Swaziland working in South Africa fell by 32 per cent from 431,000 to $294,00.3$ However, over the same period the number of men from these countries working on mines affiliated to the Chamber rose by 20,000 (See table 3). Similarly we

1 Breytenbach, op.cit. p.39.

2 Ibid p. 40

3 Ibid p.4I. 
find for all foreign Africans between 1946 and 1960 the number of women fell sharply from 110,000 to 49,000 , the number of men remained more or less constant at a little more than $440,000 .^{1}$ In the gold mines alone (including coal mines of the Transvaal) the number of foreign black miners rose by 70 per cent from 179,000 to 304,000 . Assuming that the overall statistics are reasonably accurate and that the number of foreign born workers claiming to be South African for purposes of enumeration was not significant, what seems to have been happening during the 1960's is a sharp decrease in the number of foreign workers employed in agriculture combined with an increased level of employment on the mines. That this is likely to have happened is reinforced by the fact that employment in South African agriculture is increasingly more slowly than natural population. ${ }^{2}$

As far as the mines are concerned interesting changes in the pattern of labour supply can be seen from the details of table 3 . First there is the increase, already referred to, in employment of workers from the former High Commission Territories, especially from Lesotho. Even more striking however is the increasing reliance of the mining industry upon the 'tropical areas' north of latitude $22^{\circ} \mathrm{S}$. for labour. Between the end of the Second World War and 1973 the number of 'tropicals' rose from 32,000 to 128,000. This increase took place despite the fact that the newly independent governments of Tanzania and Zambia prohibited, in 1961 and 1965 respectively, recruitment of their citizens by the gold mines. Recruiting by South Africa has never been allowed

1 sadie op.cit. p. 26

2 Basing its predictions on past trends the Department of Planning in 1972 forecast that over the period 1972-1977 the annual rate of growth of employment in Agriculture would be 1.3 per cent compared with a projected population growth rate of 2.8 per cent. Economic Development Programme for the Republic of South Africa 1972-1977 (Pretoria, I972). 
Geographical analysis, by area of origin, of black workers employed (1) on mines affiliated( 2 to the South African Chamber of Mines, (3) $1945-1974$

No. (in '000s) coming from

\begin{tabular}{|c|c|c|c|c|c|c|c|}
\hline . & in & & & & 0 & & \\
\hline $\begin{array}{r}1945 \\
46 \\
47 \\
48 \\
49 \\
1950 \\
51 \\
52 \\
53 \\
54 \\
55 \\
56 \\
57 \\
58 \\
59 \\
1960 \\
61 \\
62 \\
63 \\
64 \\
65 \\
66 \\
67 \\
68 \\
69 \\
1970 \\
71 \\
72 \\
73 \\
74\end{array}$ & $\begin{array}{r}139.5 \\
126.0 \\
113.9 \\
100.0 \\
118.8 \\
114.0 \\
108.0 \\
108.6 \\
110.1 \\
114 \cdot 3 \\
110.9 \\
116.1 \\
108.1 \\
125.7 \\
135.7 \\
145.4 \\
150.9 \\
157.3 \\
153.8 \\
139.4 \\
135.7 \\
130.5 \\
126.2 \\
129.9 \\
116.5 \\
96.9 \\
86.5 \\
87.2 \\
86.2 \\
92\end{array}$ & $\begin{array}{l}38 \cdot 5 \\
38 \cdot 2 \\
33 \cdot 8 \\
31 \cdot 3 \\
43 \cdot 0 \\
32 \cdot 0 \\
35 \cdot 7 \\
33 \cdot 4 \\
32 \cdot 8 \\
33 \cdot 9 \\
44 \cdot 3 \\
39 \cdot 9 \\
40 \cdot 1 \\
49 \cdot 1 \\
52 \cdot 7 \\
51 \cdot 4 \\
53 \cdot 9 \\
58 \cdot 5 \\
56 \cdot 5 \\
58 \cdot 5 \\
61 \cdot 3 \\
64 \cdot 3 \\
59 \cdot 7 \\
65 \cdot 1 \\
65 \cdot 0 \\
71 \cdot 1 \\
68 \cdot 7 \\
78 \cdot 5 \\
87 \cdot 2 \\
78\end{array}$ & $\begin{array}{l}7.4 \\
7.0 \\
8.8 \\
7.8 \\
9.7 \\
9.8 \\
9.1 \\
9.5 \\
9.1 \\
10.3 \\
10.5 \\
10.4 \\
11.5 \\
12.8 \\
14.5 \\
16.0 \\
13.2 \\
15.1 \\
15.3 \\
16.0 \\
20.5 \\
19.0 \\
16.0 \\
15.6 \\
14.8 \\
16.3 \\
16.0 \\
17.5 \\
16.8 \\
15\end{array}$ & $\begin{array}{l}6.0 \\
5.5 \\
6.3 \\
6.1 \\
6.3 \\
6.1 \\
5.6 \\
5.7 \\
5.9 \\
6.2 \\
5.5 \\
5.4 \\
5.4 \\
5.9 \\
5.7 \\
5.6 \\
6.5 \\
7.1 \\
5.8 \\
5.5 \\
4.5 \\
4.3 \\
3.8 \\
4.5 \\
5.0 \\
5.4 \\
4.8 \\
4.3 \\
4.5 \\
5\end{array}$ & $\begin{array}{r}95.7 \\
96.3 \\
97.1 \\
94.4 \\
102.4 \\
94.7 \\
106.5 \\
98.0 \\
96.4 \\
106.2 \\
96.8 \\
102.9 \\
99.3 \\
99.6 \\
100.7 \\
95.5 \\
100.2 \\
99.1 \\
88.7 \\
97.5 \\
102.2 \\
109.0 \\
105.7 \\
105.8 \\
99.8 \\
113.3 \\
102.4 \\
97.7 \\
99.4 \\
102\end{array}$ & $\begin{array}{c}32.4 \\
32.4 \\
39.8 \\
41.1 \\
42.5 \\
38.9 \\
41.2 \\
37 \cdot 3 \\
44.4 \\
50.9 \\
55.4 \\
59.8 \\
61.0 \\
68.5 \\
76.2 \\
82.8 \\
89.1 \\
68.5 \\
74.2 \\
71.9 \\
68.1 \\
56.3 \\
56.9 \\
61.7 \\
69 \cdot 9 \\
98.2 \\
107.8 \\
129 \cdot 2 \\
128.0 \\
73\end{array}$ & $\begin{array}{l}319 \cdot 4 \\
305 \cdot 4 \\
299 \cdot 7 \\
280 \cdot 7 \\
322 \cdot 7 \\
295 \cdot 6 \\
306.1 \\
292 \cdot 5 \\
298.6 \\
321 \cdot 8 \\
323 \cdot 4 \\
334 \cdot 5 \\
325 \cdot 4 \\
361 \cdot 4 \\
385 \cdot 4 \\
396 \cdot 7 \\
413 \cdot 9 \\
405 \cdot 6 \\
394 \cdot 3 \\
388 \cdot 7 \\
392 \cdot 4 \\
383 \cdot 3 \\
368 \cdot 4 \\
382 \cdot 6 \\
371 \cdot 1 \\
401 \cdot 2 \\
386.2 \\
414 \cdot 3 \\
422 \cdot 2 \\
365\end{array}$ \\
\hline
\end{tabular}

Source: W.N.I.A. Annual Reports.

Nores: (1) As at 3lst December, each year.

(2) Affiliated mines include all large gold mines, the coal mines of the Transvaal and one or two others (e.g. Western Platinum).

(3) In 1954 the Transvaal Chamber of Mines became the Transvaal and O.F.S. Chamber of Mines. In 1968 it broadened its constitution to include all types of mines in all four provinces. But labour recruitment by the Mine Labour Organizations (Wenela and N.R.C.) is still done primarily for the gold and coal mines.

(4) Tropical areas are defined by the mining industry as those parts of the African sub-continent lying north of latitude $22 \mathrm{~S}$. above which recruiting was prohibited between 1913 and the mid-1930's. 
in Angola althoug a few thousand men cross the border each year bound for the mines. However, the vast majority of men from the north have been recruited in Malawi. But in 1974, for reasons which will be analysed later, the number of Malawians suddenly fell by 50,000 . Although it is too early to tell for certain, examination of the figures and appraisal of the events of 1974/75 would suggest that 1973 marked the end of an era in the mining industry. Overall black employment was higher than ever before; there were more miners from Lesotho than there had ever been; the tropical areas were (over the years 1971-73) for the first time supplying more miners than any other area including Mozambique; and, parallel to all this, the number of black South Africans working on these mines was lower than it had been for fifty years or more.

\section{(c) The Contract System}

Before going on to examine the implications of these trends and of the break that seems to have occurred in 1974 let us consider for a moment the nature of the contract under which workers have come to South Africa. ${ }^{1}$ The length of stay of miners from different parts of Africa has varied considerably but has never been more than two years at a stretch. Figures for the mines of one group in 1960 reveal that the average lengths of tour, measured in shifts worked, for men from the various regions were: South Africa 245; Botswana, Lesotho and Swaziland 248; north of latitude $22^{\circ}$ south 383; and Mozambique 413. A full year is generally taken to be 313 shifts. Thus for the mining industry as a whole we see that the average length of stay during any one contract varied

1 Full details of the international contract arrangements may be found in Breytenbach op.cit. 
between 9.4 months to 15.8 months. Statistics as to the average number of contracts entered into by individual miners are not available. However, in a recent survey in Mozambique Webster interviewed 98 migrants about their mining experiences. He found that each man averaged 8 trips to the mines. The same migrants worked on an average of 6 different mines thus indicating a substantial turnover between individual mines. Overall then it would seem that, depending on the length of break between contracts, Mozambique migrants spend of the order of 12-16 of their economically active working years as miners. In Lesotho mining seems to occupy much the same proportion of the migrant's working life. In an empirical study McDowall found in 1973 that the average Basotho miner spends 35 per cent, approximately 15 years, of his working life away on the mines under 14 somewhat shorter contracts than the Mozambiquans 8 . However McDowall also found that the Basotho miners may be divided into two groups, one of which spends less than 20 per cent of their working life on the mines, whilst the other spends 45 per cent (or 20 contracts) of their working life away. ${ }^{1}$ There is one interesting change that has taken place within the contract system. Of those engaged by the mines during any one year the proportion engaged in terms of a fixed contract has increased substantially during the post war years as may be seen in the following table 4 .

1 I am indebted to $D$. J. Webster for permission to cite from his unpublished seminar paper "Iabour Migration: Problems of the Underdevelopment of Mozambique" (Univ. of Witwatersrand, Johannesburg, 1975). 
Table 4

Geographical Source

Proportion under
contract of total
number engaged (\%)

Length of contract ${ }^{1}$ (in

(shifts worked)

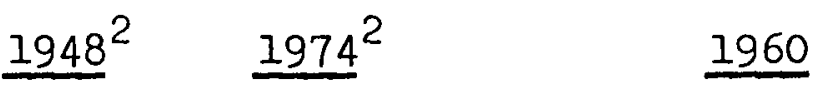

Cape Province

Natal and Zululand

Transvaal

Orange Free State

Leso tho

Botswana

Swaziland

N. of latitude $22^{\circ} \mathrm{S}$.

Mozambique

Total

$\begin{array}{r}39 \\ 4 \\ 8 \\ 331 \\ 65 \\ 76 \\ 100 \\ 87 \\ \hline 57\end{array}$

$\begin{array}{r}94 \\ 79 \\ 24 \\ 73 \\ 98 \\ 99 \\ 99 \\ 100 \\ 99 \\ \hline 96\end{array}$

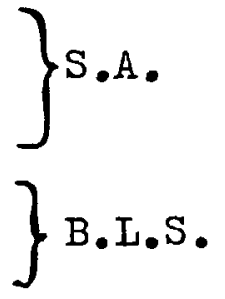

245

248

383

413

Source: N.R.C. Annual Reports and F. Wilson, Labour in S.A Gold Mines, p.73

Notes: 1. These refer to mines of one Group only.

2. The year refers to the 12 months ending 30 June.

Between 1948 and 1974 when the total numbers engaged rose

from 261,000 to 315,000 the proportion under contract of all

black mine workers rose from 57 per cent to 96 per cent. This

change was due primarily to the decline of the Assisted

Voluntary Scheme in terms of which men from within South Africa

and the former High Commission Territories were allowed to

choose their own mine and work for as little as four months

at a time. But if they stayed for less than 9 months their

rail fares, which were advanced to them by the Native

Recruiting Corporation, had to be repaid. Since the primary purpose of the A.V.S. scheme was to enable men to stay for a shorter period of time than the usual N.R.C. contract (270 shifts i.e. approximately 10 and a half months) we may safely assume that during the post-war years the length of time spent at the mines during each tour by the average migrant has 
increased. 1 This is particularly taue of those from within South Africa and the former High Commission territories but applies also to Mozambique. Men from the tropical areas however have always been almost entirely under contract.

\section{(d) Summary}

Summarising the position we may say that in Southerm Rhodesia by 1973 there were some 890,000 Africans employed in the economy as a whole: of these approximately 200,000 (this figure is for 1969) were foreign born, 120,000 of them working in agriculture. But the annual inward and outward flows of migrants had fallen to a mere trickle. ${ }^{2}$ The Southerm Rhodesian labour market was, in Duncan Clarke's terms, being "internalised". In South Africa in 1973 there were some 475,000 foreign-born Africans employed. Of these, as may be seen in the following table 5, the majority were oscillating migrants at work on the mines.

1 It is worth noting that in 1930 a study of black mineworkers from South Africa and the High Commission Territories found that their average length of serve on the mine was 10.9 months. However, closer examination of the sample shows that it contained relatively few A.V.S. men whose average length of service was approximately 6.2 months. Yet during the early 1930 's A.V.S. men formed a large proportion (of the order of half) of the miners draw from South Africa and the High Commission Territories. The sample drawn was unrepresentative because it drew only on men who were discharged in November, a time of the year when most men choosing to work for 6 months at the mines would already be back home for agricultural purposes. The decline of the A.V.S. men is a pointer to the increasing pressure on land in the Bantustans. Sources: Union of South Africa, Report of the Native Economic Commission 1930-32

(U.G. 22, 1932, Pretoria) pp.212-213. N.R.C. Annual Reports (Johannesburg).

2 A. M. Hawkins, "African Unemployment in Rhodesia", The Rhodesia Science News (Vol. 8 No. 7, July 1974) pp. 213-214 Breytenbach op.cit. p.63. 
Table 5

Foreign Africans at work in South African Economy, 1973

Country

of

Birth
Total Employed No. Employed ${ }^{(1)}$ on mines in South Africa Affiliated to the Chamber

$000 \mathrm{~s}$

(A)

Approximate No. $B$ as proEmployed else-where portion of $\mathrm{A}$ $(4)$

$000 \mathrm{~s}$

\begin{tabular}{|c|c|c|c|c|c|}
\hline $\begin{array}{l}\text { Leso tho } \\
\text { Malawi }\end{array}$ & $\begin{array}{l}149 \\
140\end{array}$ & $\begin{array}{l}31.4 \\
29.4\end{array}$ & $\begin{array}{r}87 \\
128\end{array}$ & $\begin{array}{l}62 \\
12\end{array}$ & $\begin{array}{l}58 \\
84\end{array}$ \\
\hline $\begin{array}{l}\text { Mozam- } \\
\text { bique } \\
\text { Botswana } \\
\text { Swaziland } \\
\text { Other }\end{array}$ & $\begin{array}{r}127 \\
36 \\
10 \\
13\end{array}$ & $\begin{array}{r}26.7 \\
7.6 \\
2.1 \\
2.7\end{array}$ & $\begin{array}{l}99 \\
17 \\
5 \\
x\end{array}$ & $\begin{array}{l}28 \\
19 \\
5 \\
x\end{array}$ & $\begin{array}{l}78 \\
47 \\
50 \\
x\end{array}$ \\
\hline Total & 475 & 100 & 336 & 139 & 71 \\
\hline
\end{tabular}

Sources: House of Assembly Debates No. 10 Col. 687 (8.10.1974). W.N.I.A. Annual Report.

Notes: (1) Figures for mines are for employment as at 31 December and hence are not strictly comparable with those, for S.A. as a whole, listed in the first column which refer, it seems, to average employment during the year.

(2) These figures include miners from all areas $N$. of lat. $22 \mathrm{~S}$. The vast majority however are from Malawi.

(3) These figures are included with those under (2) above.

(4) i.e. Agriculture, manufacturing and also mines not drawing their labour through the Chamber's Mine Labour Organisations.

From these figures we see that of the 475,000 foreign Africans at work in South Africa in 1973 some 336,000 (71 per cent) were employed in those mines that were affiliated to the Chamber of Mines. Of the remaining 139,000 it is likely that a substantial number were in agriculture but also in some of the other mines, eg Platinum and Copper, which were not affiliated 
to the Chamber for purposes of labour recruitment. At this period the total number of Africans in paid employment within South Africa was estimated to be between 3 or 4 million. of these approximately 1.4 million African workers, both regular and casual, were employed on white farms; 697,000 in manufacturing; 641,000 in mining; 284,000 in construction; and the rest in other sectors of the economy, not least in domestic service. $^{1}$

III. The Impact of Immigration

(a) Southern Rhodesia

In Southerm Rhodesia it is in the agricultural sector that foreign migrants have been concentrated and here clarke finds that the real average eamings of African labourers were "probably lower in 1972 than in 1948". 2 In 1972 when foreign borm Africans formed over one third $(120,000)$ of all those employed $(338,000)$ in Southern Rhodesian agriculture, the annual average earnings were 135 dollars which worked out at a little over $\$ 11$ per month. Nearly three quarters (73 per cent) of the farm labour force receives a cash wage of less than $\$ 10$ a month. Clarke argues, and from the opposition of the Rhodesian Agricultural Union to restrictions placed on the use of foreign workers ${ }^{3}$ it would seem that he is right, that the influx of foreign migrants particulary during the 1940's and 50's had a significant impact in holding down wages particularly in the agricultural sector.

But low wages is not the only problem affecting blacks in Southern Rhodesia: there is also the growing unemployment. Despite the difficulty of obtaining a clear definition and measurement of unemployment and underemployment in a developing

1 Muriel Horrell, Dudley Hormer and Jane Hudson, A Survey of Race Relations in South Africa 1974 (S.A. Institute of Race Relations, Johannesburg, 1975) pp. 262-3I4.

2 D.G. Clarke "Farm Worker's Wages and Conditions of Employment from the 1940's to the 1970's" The Rhodesian Science News

(Vol. 8 No. 7, July 1974) p.20\%. 
country with a large subsistence sector, A.M. Hawkins writes that during the 1960's "one cannot escape the conclusion that African unemployment or underemployment must have risen over the period". " Moreover he goes on to argue that "in the next ten years the modern economy will find it extremely difficult - if not impossible - to meet the expectations of the rapidly growing supply of increasingly educated job seekers". Over the period 1965 to 1974, during which time there seems to have been a net emigration of Africans from Southern Rhodesia, the black population grew at an estimated annual rate of 3.1 per cent. From evidence in Western Europe one knows the fallacy of believing that unemployment is necessarily correlated with the number of foreign migrants and of arguing that pushing out the foreigners will necessarily improve the unemployment position vis-a-vis local citizens. Nevertheless it is clear that Southern Rhodesia could not, in 1975, employ vast numbers of foreign oscillating migrants in agriculture as it did during the 1950's and 60's without significantly aggravating the internal unemployment position.

(b) The Republic of South Africa

If we look at the mining industry in which the foreign migrants have been concentrated, we find that in the gold mines over the period 1911 to 1969 the real value of black cash eamings did not rise at all and may in fact have actually fallen. But it is in the period of rapid industrialisation of the South African economy since the mid-1930's that the impact of the migrants upon earnings in the mining sector can most clearly

1 Hawkins op.cit. p.211. 
be seen. In 1936 the 3,000 miners from north of latitude $22^{\circ} \mathrm{S}$. constituted approximately 1 per cent of the mine labour force: by 1960 their number had risen to 83,000 and they made up just over one-fifth ( 21 per cent) of the mine labour force. Over the same period the number of black South Africans on the mines fell from 166,000 (52 per cent) to 145,000 or 37 per cent of the total African mine labour force. Cash earnings in the manufacturing and gold mining sectors in 1936 were $R 84$ and R68 per annum respectively: in 1961 the figures, in current terms, were R370 and R146 per annum. In other words over the period 1936 - 1961 the ratio of manufacturing to mining wages for blacks in the two sectors had widened from $1.2: 1$ to 2.5:1. In real terms manufacturing wages had risen substantially whereas those on the mines had actually fallen. In the manufacturing sector, over the period 1935 - 1970, the average white wage as a proportion of the average black wage rose from $5.5: 1$ to 5.7:1. But in the mines the gap was not only far greater but, between 1936 - 1971, widened more dramatically from 11.5:1 to $21.0: 1.1$

of course the influx of foreign migrants was not the only factor influencing wages in the mining sector: there was the well organised collusion of the mining houses to hold wages down; there was the colour bar; there was the massive resistance to black mineworkers trade unions and strikes. Nevertheless it is clear that the access which the mining industry had to labour from areas north of latitude $22^{\circ} \mathrm{S}$, especially from Malawi, which was not available to the manufacturing sector, was a crucial factor in determining the shape of the wage structure as it emerged in the quarter century following the second World War.

1 Francis Wilson, Labour in the South African Gold Mines 1911-1969 (C.U.P., Cambridge, 1972) pp.46 and 67. If allowance is made for food received by biack miners the earnings gap between white and black widened from 10.7:1 in 1936 to $17.9: 1$ in 1969. 
(c) The Present and the Future in the Mining Industry

At the beginning of the 1970 's there were some marked changes in the gold mining industry, but these too were intimately related to the migrant patterns. By 1968-70 the mining industry was faced with a crucial decision: worried by the rapidly declining number of black South Africans willing to come and work on the mines (see table 3) the industry realised that within a few years the number would fall to nothing as more and more blacks were absorbed at higher wages elsewhere in the economy. Two alternative policies were debated: either the mines must take steps to compete with manufacturing and draw back South Africans or they must move still further afield to recruit labour and become 100 per cent dependent on foreign workers. When the price of gold rose employers decided that the risks and costs, not least in political terms, of the latter course were too high and so they opted for a policy which would lead to the employment of more South Africans.

It was an historic decision. Ever since the mines opened in the 1880's the employers, when faced with labour shortages, had simply moved further and further afield to draw in labour from economies which acted essentially as labour reserves.

As this decision was being reached a number of separate, not all related, but uncannily interlocking, events reinforced the mine owners in their decision and made it possible for them to do something about it. First there was the dramatic increase in the price of gold. The average revenue received by the industry per fine ounce of gold sold more than quadrupled from R25.8 in 1970 to R107.4 in 1974. Then, in September 1973, came the first of the compound confrontations which over the next 18 months were to erupt all over the mining industry and 
lead to the death of no less than 132 men. ${ }^{1}$ Then in April 1974 came the crash of a Wenela aircraft near Francistown in Botswana which killed 72 Malawian miners. As a result of this President Banda decided to suspend the recruiting of all Ifalawians pending an investigation into the causes of the crash. A year later the embargo was still in force and the mining industry was severely embarrassed by the shortage of labour brought about not only by the failure of new Malawi recruits to arrive but also by the fact that Malawians already on the mines, disturbed not least by lack of information from home which would normally have come in with new recruits, decided to go home before their contracts had expired. Between the 31 st of December 1973 and 1974 the number of miners from north of latitude $22^{\circ} \mathrm{S}$. was reduced from 128,000 to 73,000 .

These factors, together with the fall of the Portuguese empire in April 1974 and the emergence of Frelimo as the governing party in Mozambique, combined to strengthen the determination of the mining industry to do what it could to reduce its dependence on foreign labour. Thus wages were increased substantially: between 1972 and 1974 average annual cash earnings, in current terms, rose from $\mathrm{R} 257$ to $\mathrm{R} 565 .^{2} \mathrm{By}$ June 1975, the minimum wage on the gold mines was $R 2,20$ per shift, over five times higher than it had been three years previously. But, although the number of black South Africans coming to work on the mines did rise between 1973 and 1974 (from 86,000 to 92,000 ) this wage increase alone was not sufficient to reduce substantially the industry's dependence upon foreign labour.

other than raising wages there are broadly two sets of measures which employers of labour can attempt to use as they seek to overcome a shortage. On the one hand there are steps to influence the demand for labour; on the other, action to shift the supply. on the deman'd side the possible ways of reducing the need for labour on the mines were (a) improved management, (b) mechanisation and (c) training. The first of these was precipitated by the

\footnotetext{
1 Francis Wilson, "Compound Confrontation". Sunday Tribune (Durban, 9.3.1975)

2 Chamber of Mines of South Africa, Annual Report 1974 (Johannesburg, 1975.
} 
by the unexpected and rapid withdrawal of Malawi labour following the April 1974 aircrash in Botswana. The industry, in the words of the President of the Chamber of Mines, found somewhat to its surprise the it did not "really require so many workers". ' To some extent the ability of the industry to weather the drop in the number of Malawi workers by 50,000 during 1974 was a short term success due to the possibility of taking men off development work and into the extraction of ore at the stope face.

In the long $r n$, development work has still to be done and the possibility of using less labour is more circumscribed. However it does seem that the sudden withdrawal of labour did force upon the industry a certain amount of reorganisation which enabled gold to be mined with rather less men.

The second step, about whose potential there is considerable disagreement, is the mechanisation of mining. According to some engineers within the industry the potential for mechanisation is in fact severely limited by the nature of the ore body, which at a depth of up to 2 miles and with a width of less than 2 feet in broken reefs which do not always run continuously, is extremely small. On the other hand the industry in mid 1974 embarked upon a 10 year research programme estimated to cost R100 - R150 million into methods of mechanisation, including the replacement of explosives by boring machines. According to some estimates this machine, if successfully developed, could reduce stope labour complements by some 50 per cent. 2 However it is still too early to tell whether or not mechanisation is going to be able to affect substantially the number of men needed to dig out a given amount of ore. One can simply note that, with the substantial wage increases (at least relative to what they were) and the withdrawal of Malawian labour, the mining industry is, for the first time since the discovery of gold, under severe pressure to mechanise in a way that it has never been before.

I A.W.S. Schumann, "Mine Iabour: The Fast Changing Scene" Mining Survey (No. 76, April, 1975) p.4.

2 Ibid p. 37. 
A third possible step to increase labour productivity is training and education of workers. The mining industry has for many years been investing a considerable amount in training but as far as black workers are concerned its effectiveness is limited both by the colour bar which prevents them from doing jobs beyond a certain skill level and by the migrant labour system which implies a high rate of turnover. However, due to the shortage of white miners the colour bar is beginning to shift and although, as of 1975, there has been $\mathrm{nc}$ change in the law it nevertheless seems likely that changes may come in this area so that in the near future blacks will officially be doing more highly skilled jobs. So too it is possible that pressures will lead to a substantial increase in the proportion of black workers allowed to live permanently near the mines with their families. But until that happens further training is unlikely to do much to reduce the demand for labour.

Turning now to the supply side there are a number of steps that the mining industry has taken. First it has applied successfully for relaxation of a regulation which made mine work particularly unpopular amongst blacks living in the cities. This was the rule which obliged the mining industry to return (at the end of his period of service) any South African recruit, irrespective of where he had been recruited, back to his particular ethnic homeland. The mines have, since 1974, been allowed to return any black miners recruited in the urban areas to the towns whence they came. Secondly, the mines have stepped up nationwide publicity for recruiting. This has been done particularly via Radio Bantu, which reaches into all corners of the Republic not least onto the white farms. The use of Radio Bantu combined with the new wage rates means that many people living on the farms are, for the first time, being directly approached with information about job opportunities at wages which are well above 
those paid by agriculture in most parts of the country. This does not mean that farm labourers are free to leave the farms and go to work on the mines, for pass laws bind such workers and their families to the land. However, there can be little doubt that agricultural employment is not increasing as fast as is population as a whole. Thus there is a labour surplus in South African agriculture which, potentially at least, is available for work on the mines. Combined with this is the fact that during the post war period the political balance of power within the ruling National Party has undoubtedly shifted to some extent away from farming towards urban interests. This is not to say that farming interests are all that weak but that they are not as powerful as once they were. With the decrease, since the early 1930's, in the number of whites living on the land there is growing insistence on the part of urban employers that farmers should not enjoy special protection which enables them to employ black labour at wages far below the levels of manufacturing and, more recently, the mining sectors. An indication of this shift within the white political power structure, may be seen in the 1974 broadcasting programme run by the Statecontrolled S.A.B.C. which highlighted the appallingly low wages paid by many, though not all, farmers. Such a programme would have been unthinkable only a few years ago and its transmission was a significant event. ${ }^{1}$

Despite all these steps to change wages and other variables both on the demand and the supply side, the mining industry was nevertheless unable, in the short run at least, to rely only on the South African labour mat in order to cushion the full shock of the Malawi withdrawal. At the end of 1974 an agreement was

1 It is worth noting however that attempts were being made by Govermment in 1975 to restrain mines from making too frontal an assault on farmers' labour supplies. Star (12.6.1975). 
reached with the Southern Rhodesian Government whereby, for the first time since 1912, the mining industry was permitted to recruit some workers from within Southern Rhodesia. The first miners arrived early in 1975 and by the beginning of May there were some 2,100 Southern Rhodesian Blacks at work on the South African mines. The extent to which this labour supply will expand in the future, whether under a Southerm Rhodesian or a Zimbabwean Government, is unknown; but it is worth noting that in June 1975 the minimum wage for an underground miner in South Africa was R2,20 per shift whilst for a Southern Rhodesian miner it was 31 cents. 1 Thus, it is quite clear that if any future govermment were to allow free recruitment inside Southerm Rhodesia or Zimbabwe there would be a large number of men willing to work on the South African mines. Discussion as to whether or not widespread recruiting for the South African mines would be in the best interests of the people of Zimbabwe lies outside the scope of this paper.

\section{(d) Agriculture}

Mining is not the only sector that has been affected by the changing patterms of international migration over the years. The agricultural sector has been influenced both directly and indirectly by the migrant flows. The direct impact is hard to measure, not least because official statistics for both South African and non-South African farm labour ar so imprecise. It does seem.likely that farming in the Orange Free State, for example, would not have developed in the way it has if the Iesotho labour, especially for harvesting, had not been available. Without going into the pros and cons of such migration let us simply note that the influx of labour from outside the political boundaries will almost certainly have affected the nature of the economic development of that agriculture. But, as in Southern Rhodesia, the agricultural sector has become far less dependent on foreign labour than it was during the 1950's and 1960's.

1 Financial Mail. The minimum of 26 cents given in the F.M. is assumed to be in Southern Rhodesian currency which converts to 31 cents, South African. 
With regard to the indirect effects of intermational migration these can perhaps most clearly be seen by considering what has happened in the Natal sugar industry during the first half of the 1970's. Much of the seasonal labour for cutting cane has come for many years from Pondoland and the surrounding districts of the Transkei. By recruiting 20,000 migrants a year on 180 day contracts from this area the sugar industry was in direct competition with the gold mines as it discovered in the 1970's when wages on the mines first started to shift substantially. These increases affected the supply of labour to the Natal sugar plantations and the farmers had to take steps to raise wages in order to ensure their supplies. over the four years 1971-4 field wages approximately doubled in current cash terms. The cane cutter's basic wage, excluding bonuses, was raised in December 1974 from $R I$ to $R 1.25$ per day and in. April 1975 raised again to \%1.75 per day. "Undoubtedly", wrote the Financial Mail, "the size of the present hike has been prompted by the threat from the mines". I

The action of the Natal sugar industry highlights the nature of the interrelatedness of migrant labour markets in Southerm Africa. One can see how the inflow, since before the Second World War, of "Tropicals" held down wages on the mines which, in turn, made it possible for those farmers employing migrants to pay lower wages than they would otherwise have done.

However, it is important to note that the inflow of foreign migrants to the mines was not necessarily responsible for holding down all wages in the agricultural sector. Labourers who were not migrants but living permanently on the farms were rendered immobile by pass laws, indebtedness, and other factors which isolated that labour market from what was happening elsewhere.

1 Financial Mail $(7.2 .1975)$. See also ibid (13.12.74.) 
At the same time it is interesting to note that there has been some correlation between the behaviour of earmings in the two sectors. Both on farms and on the gold mines the evilence suggests that, assuming the statistics are not too shaky, cash earnings in real terms did not rise and may well have fallen since the 1880 's. ${ }^{1}$ At the same time Merle Lipton has shown that the real wages of farm labourers have risen during the $1960 \mathrm{ss}^{2}$ on the mines also wages rose in real terms during the 1960's and by 1969 had risen to where they were in 1911. This combination of no change over 80 years or more plus a rise over a particular decade is possible when one remembers that, in the case of the mines, there was a sharp decrease in real terms of mine wages during certain periods due to inflation. During the first half of the 1970's when average black earnings on the gold mines more than doubled whilst those in manufacturing and construction sectors also rose farmers in many parts of the country found themselves increasingly short of labour and compelled to raise wages substantially. ${ }^{3}$ Thus overall we find a similarity of wage behaviour in the two sectors which suggests that, despite the extent of barriers to the mobility of farm labour, there was nevertheless some interaction between the two labour markets. If this is true we may well expect substantial changes in the farm labour scene during the second half of the 1970 's as the impact of wage increases in the mining industry makes itself more fully felt not only amongst migrant workers but in the less mobile section of the farm labour force.

1 Monica Wilson and Leonard Thompson (eds.), Oxford History of South Africa (Clarendon Press, Oxford, Vol. 2, I971) pp. 160-161. F. WiIson, Gold Mines op. cit. pp. 45-46.

2 Merle Lipton, "White Farming: A Case Study of Change in South Africa", Journal of Commonwealth and Comparative Politics, Vol.XII, No.1, March 1974, p.47.

3 There is, as yet, no statistical evidence for this assertion which is based on impressions gained, during his profession work as an agricultural journalist, by Symond Fiske (personal communication, May 1975). 


\section{(e) Psychological Effects}

The impact on the wage structure through international migration is not the only aspect to be considered. There is need to explore three further dimensions of the matter, namely psychological effects, labour control, and capital accumulation. A major psychological (and sociological) effect of labour migration relates to the familiar phenomenon whereby work performed by migrants or outsiderscomes to be regarded by nonmigrants or insiders as being of too low a status for them to do themselves. In the context of South Africa one might label this attitude the "dim k.w." syndrome in recognition of the notorious rejection over the years by whites of various types of work. "Dit is mos kaffir werk" ("That is simply kaffir work"), summarised in a phrase the contemptuous attitude towards certain jobs as being beneath the dignity of white men. However, the "dim k.w." syndrome is not confined to whites (nor indeed to Southern Africa). ${ }^{1}$ A major problem with which the mining industry has to contend, as it seeks to employ less foreign migrants, is that mining is widely regarded by black South Africans as lower class work. Hence, even as wages improve, there is resistance to undertaking what has, over the past 40 years, become a relatively low status job. ${ }^{2}$ of course migration as such is not the only factor causing the "dim k.w." syndrome wherever it occurs. Low wages and patterns of education, to name only two, also contribute to this attitude. But it is clear that migrant systems are an important cause of psychological resistance to certain types of work. And this resistance in turm is part of the reason why unemployment in a country cannot simply be eliminated by sending migrants back to the countries whence they came.

I As an example of the "dim k.w." syndrome in Western Europe consider, "The fact ...... that the immigrants do jobs that native Europeans would rather be unemployed than do", Jonathan Power, "The New Proletariat" Encounter (sept. 1974) p.9.

2 Evidence for this comes from Kimberley where, according to management, a major difficulty in the diamond mines policy since 1972 of phasing out the migrant labour system. was the unwillingness of local blacks to do some of the jobs (e.g. loading ore by hand shovel) which previously migrants had done. So the mines changed the method of loading. 


\section{(f) Labour Control}

With regard to labour control it is important to note that perceptions varied not only between individuals and groups but also according to different historic circumstances. Thus in the years that followed the second World War we find that employers of mine labour on the copper belt of Zambia (then Northern Rhodesia) were persuaded that the migrant labour system was a cause of more socio-political difficulties than would be a stable labour system. In the gold mines on the other hand employers argued, not always explicitly, that a migrant labour force was much easier to control. As far as the South African mines were concermed the control of labour was facilitated by at least three aspects of the migrant system.

1. Because of the annual rate of turnover it was relatively simple to weed out "agitators" either by not renewing their contracts at the end of a term of service or by dismissing them and returning them to their home area. Indeed the fact that men came from so far away enabled the mines to use the threat of dismissal as a more powerful weapon than it would have been had the men being living permanently near the mines and able to move to some other sector should they need a job.

2. Strikes, picketing and other forms of worker action could be rapidly contained by sealing off the mine compounds all of which had clearly defined entrances.

3. Any group of workers proving really difficult as far as management was concerned could simply be dismissed, sent back to their home areas, and replaced by workers from there or elsewhere.

Of course the above three factors are not always the exclusive prerogative of employers of migrant labour. Any serious unemployment whether of migrants or others does give employers more power than they would otherwise have. Nevertheless it does seem likely that the relative absence of strikes in the South African 
mining industry over the past century is not unconnected with the enormous power of control that the mines and also the police are able to exercise over the movement, assembly, and general lives of the mine workers.

However, by the 1970 's a number of variables seemed to have been changing in such a way that the migrant labour system is no longer seen as necessarily best from the point of view of employers wishing to control labour. Two interrelated factors have given mine management considerable food for thought in more recent years. One is the rash of compound confrontations that swept through the mining industry (not only gold mines) during the 18 months September 1973 to February 1975. During this period over 130 men were killed and almost 500 injured in some 25 different confrontation in mines in all four provinces of the Republic of South Africa. It is being widely argued, and mine managements fear, that these confrontations although difficult to analyse and explain are in some way related to the nature of the migrant system which keeps men housed on a single basis in vast compounds, hostels, or "labour batteries" of up to 8,000 men.

The other new development is the proclivity of the mine workers to walk off their jobs before the end of their contracts, leave the mines, and return to their rural homes. This has involved not only a very large number of Malawian workers following the Botswana air crash in April 1974 buthas also occurred after several of the compound confrontations.

These two factors now mean that the mining industry is considerably more sensitive than it was to the possibility of the migrant system involving the mines in far higher costs, due to disruption and worker walk-outs, than would a more stable labour system. For example, had all the Malawian mine workers been living as full-time miners near their place of work with their families it is unlikely that, over a single 12 month period, some 50,000 of them would have left the mines. The fact that migrants from a particular geographic area tend to act together when it comes to walking off a mine has meant that individual mines 
are unwilling to place their reliance upon labour from any one particular area. Suggestions for housing mine workers in compounds on a uni-ethnic basis in the hope of reducing compound confrontations are unlikely to be adopted because management fears that such uni-ethnic compounds might empty overnight during a given crisis in a way that they would be less likely to do were workers drawn from a number of different areas. This aside however, the mines are increasingly aware of the high risks of employing workers on a migrant basis and it is possible that during the next decade we shall witness substantial changes as mines exert pressure to stabilise their labour system.

(g) Capital Accumulation

Turning now to the fourth dimension of the migrant system let us consider the way in which it affects the process of capital accumulation. Two aspects seem especially important. One relates to the lower labour costs which a migrant system often makes possible: the other is that capital accumulated, (of which company tax and reinvested profits form part), is not necessarily used for the benefit of the full community which supplied the labour. Looking at the gold mining industry, for example, it has been argued that without the migrant labour system which obviated the necessity of the gold mines paying either an urban wage sufficient to keep a worker and his family or the rates to build houses and the rest of the urban infrastructure it would have been impossible for the mines to develop as they did. In other words the migrant system has enableda more efficient allocation of resources to take place and hence economic growth, including the creation of jobs, to occur in a way that would not have happened had the oscillating pattern not been possible. On the other hand it can be argued that because the migrants had almost no political power the capital surplus or social dividend that was available once the various factors of production had been paid was seldom used primarily for the benefit of the communities from which the migrants come. ${ }^{1}$

1 We are not primarily concermed in this paper with the question as to whether or not the share between different factors of production should be other than it is. Our argument focusses on the shape of capital accumulation flowing from such sources as taxation and retained profits. 
In the South African context we find that the tax revenue derived directly from the gold mines themselves has been used largely for the benefit of whites in whose favour public expenditure is heavily biased. Nor is it only a question of skin colour. National boundaries too have, as elsewhere, been used to deliniate differences. Thus very little of the tax revenue or the reinvested profits ${ }^{1}$ derived directly from the gold mining industry have found their way to Lesotho or Mozambique despite the fact that these countries have been supplying over 40 per cent of the black labour force for 80 years or more.

The nub of our argument is that whilst the migrant system may at a certain stage (which in South Africa we believe is long past) facilitate that primitive capital accumulation without which no economic growth takes place, it is important to recognise that such capital accumulation does not necessarily benefit everybody equally. For the pirposes of our analysis so far however, we note simply that international migration in Southerm Africa has been of immense benefit to the Republic of South Africa (and to Southerm Rhodesia) not least because of the capital accumulation it has made possible.

\section{The Impact of Emigration}

But what of the impact of migration on the sending countries? Has this, as conventional international trade theory would suggest, been of benefit to these countries or is it possible that some other mechanism has been at work whereby the countries have suffered as a consequence? There is a wealth of literature dealing with this question but, as yet, no consensus as regards the answer. Within Africa the problem has been brought most sharply into focus in the West where Elliot Berg and Samir Amin have

1 When they first. started the South African mining groups had few internal resources. However, as time went on, the groups began to build up financial reserves from jobbing and from the services they provided to individual mines. Some of the profits from this were invested and the groups acquired a third source of income in the form of dividends. Over the seven years which began with the declaration of the first Orange Free State divident in 1954, the investment income of the Anglo American Corporation alone trebled from R5.2 million to RI6.4 million. Another seven years later, by 1967, the figure had risen to R28.6 million. Source: Wilson, GoldMines op cit p.25. 
come to radically different conclusions in their assessments of the impact of labour migration in that part of the continent. ${ }^{1}$ We shall not attempt to summarise that debate here but shall draw on it as we seek to weigh up the different assessments of the system in the South.

On the one hand there are those, like G.M.E. Leistner, who argue that "the fact that these men (non-South African migrants) are living off the resources of another country rather than augmenting the number of those trying to eke a minimum subsistence from traditional agriculture at home, is a definite advantage. Beyond that .... the various countries derive direct benefit from the cash and goods brought or sent back ("remitted") by migrants in the Republic, and also from: the activities of the recruiting agencies." 2 on the other hand another South African, Sam Nolutshungu, warns against "the rather pat view" that a sending country like Malawi benefits all round from the migrant labour system, particularly in the long run. "It is very doubtful", he writes, "whether economic co-operation with South Africa will accelerate economic development of a kind that will be optimal for the whole of Malawi society." 3

(a) Short-run Benefits: Individuals and Remittances

In assessing these divergent views let us start at the micro level by considering individual migrants and the short term

1 Elliot Berg, "The economics of migrant labour systems", in Hilda Kuper (ed.) Urbanization and Migration in Africa (Univ. California Press 19795$)$. Samir Amin (ed.) Moderm Migration in Western Africa 2 G.M.E. Leistner, "Foreign Bantu Workers in South Africa: Their Present Position in the Economy" S.A.J.E., March 1967, p.40.

3 Sam C. Nolutshungu, South Africa in Africa (Manchester Univ. Press, Manchester, 1975) pp.212-3. 
consequences of their migration. Clearly individuals would not migrate unless on balance they thought that by so doing they would improve their position. In Malawi, for example, Dr. Margaret Read found during anthropological study in 1942 that "it is evident throughout the villages under investigation that standards of living are changing rapidly and that emigration on the whole is making them rise rather than fall." 1 Twenty years later Van Velsen, who had also done his field work in Malawi, concluded in 1961 that "compared with other tribal areas the Tonga are relatively prosperous; this prosperity is largely due to their export of labour". 2 Similarly a decade later Nolutshungu was in no doubt that, "in financial terms, migrant labour ..... of the sort operating between Malawi and South Africa, was beneficial" to the sending country. 3

The financial benefits both to migrants and the communities from which they come are derived, of course, primarily from the earnings paid by employers. These may be spent by the migrant on himself and his friends at his work place; they may be spent in order to purchase goods which he sends or takes home when he returns; they may be sent home in the form of remittances, deferred pay, tax, or simply as cash taken back at the end of a contract. It is difficult to measure the extent to which those who remain behind benefit from the earnings of the migrants working

1 M. Read, "Migrant labour in Africa and its effects on tribal life", Intermational Labour Review (Vol. XLV, 1942).

2 J. van Velsen, "Labour Migration as a positive factor in the continuing. of Tonga tribal society", in Aiden Southall (ed.) Social Change in Moderm Africa (O.U.P., London, 1961).

3 Nolutshungu op.cit. p. 212 
in another country, but it is clear that for the sending community as a whole, including migrants as well as those who remain behind, the total income will rise as a result of migration.

In terms of intermational government agreements between South Africa and the sending countries both Mozambique and Malawi require their workers to send home a certain proportion of their earnings. As far as Mozambique is concerned these earnings had, in terms of the Mine Iabour Agreement between the Republic of South Africa and Portugal, to be sent home either as family remittances or as deferred pay which the worker received upon his return to Mozambique at the end of his contract.

Similarly Malawi, in terms of its agreements with Wenela (1965) and the South African Government (1967) requires that after six months service, not only family remittances to the amount of $R 8.00$ must be sent to the nominee of a recruit in Malawi, but also that 60 per cent of his monthly wages must be sent "for the purposes of deferred pay, to be paid to him in the presence of a govermment representative immediately after his return to Malawi. ${ }^{1 "}$ The agreements also made provision for Wenela to deduct and pay direct to the Malawi Govermment the taxes due to it by its citizens working in the gold mines. It is general practice for foreign oscillating migrants to be held liable for direct tax in their country of origin rather than in South Africa. As far as Malawi is concerned the 1965 agreement also made provision for Wenela to pay the Malawi Government a 50 cent attestation fee for each contract of service, 10 cents for each month's service rendered by a recruit in South Africa, and a fee of $\mathrm{R} I 2$ per year per head for the first 20,000 recruits and $R 6$ per head thereafter. Thus if,

1 Breytenbach op.cit. 
for example, there were 100,000 Malawians working in a given calender year on the mines their government's revenue excluding direct and indirect taxes of the migrants' earnings would have been approximately R890 000. Other indirect benefits were derived from expenditure by recruiting organisations in Malawi for such things as staff salaries, contributions to the govermment welfare fund, and transport of migrants. In 1967 the net capital inflow from such expenditure in Halawi was estimated to be $£ 316,0000^{1}$

In Botswana there is also legislation which compels migrants to send home a certain amount of their pay. In Lesotho there were no compulsory regulations until the beginning of 1975 when the government of Lesotho announced that with immediate effect all Basotho mine workers would be required to repatriate 60 per cent of their eamings to be paid into the Lesotho National Bank and not withdrawn until the worker came home at the end of his contract. This unilateral action, which had been taken without consultation with the workers concerned, provoked an immediate and explosive response in the form of compound confrontations at several gold mines and two collieries. Some concessions were made but the principle of compulsory deferred pay was maintained.

The extent to which sending countries benefit both directly and indirectly from the earnings of their migrants is difficult to calculate exactly. In 1970 the remittances and deferred pay of mine workers sent through and recorded by the various recruiting organisations were as follows. Malawi R6.7 million: Lesotho R4.4 million; Botswana Rl.l million; Swaziland R0.6 million. ${ }^{2}$ By 1972 the Lesotho figure had risen from R4.4 million to R5.8 million.

\footnotetext{
1 Nolutshungu op.cit. p.212.

2 Breytenbach op.cit. pp.45 and 57.
} 
But these figures are not a full reflection of the value of earnings returning to the labour exporting countries. In Lesotho, for example, on the basis of empirical research McDowall finds that the total financial return, including informal remittances, cash in hand and goods carried by returning migrants for the year ending mid-1973 was R15.9 million as compared with the official figure of R5.8 million for 1972. 1 He estimates that the average Lesotho miner repatriated $\mathrm{R} 160$ (nearly two-thirds) of his 1972 annual earnings of some R260. How much of his 1974 annual earmings of R565 were repatriated is not known.

Similar adjustments, after empirical research, would need to be made to the official figures of remittances and deferred pay to the other labour exporting countries. With regard to Mozambique it has been estimated that in 1971 mine workers remittances were $\mathrm{R} 50$ million or 17 per cent of GDP. ${ }^{2}$ In 1975 this figure will be considerably higher because remittances paid in terms of the intergovernmental agreement are paid in gold valued at the official price of $\$ \$ 2$ a fine ounce whereas the free market price is approximately four times higher. Previously the gold received was flown from Lourenco Marques to Lisbon but one early result of the Portuguese developments in 1974 was Mozambique's insistance on keeping the windfall profits for herself.

(b) Short-run Costs: Agriculture and Income Distribution

So much then for the immediate benefits to the sending country of the oscillating migrations: what of the costs? First there is the fact that in many instances home agriculture has deteriorated as full-time farmers move off the land to the

1 M. McDowall, "Basotho Labour in South African Mines - An Empirical Study". (mimeo, October, 1973).

2 Financial Mail $(21.6 .1974)$. 
cities as oscillating migrants, thus devoting only a fraction of their time in any year to their farms. As Schapera wrote of Botswana at the beginning of the Second World War, "owing to labour migration, many people are no longer available at home to attend the routine tasks of tribal life, and as a result both animal husbandry and agriculture have suffered."I Similarly Germond, who knew Lesotho and the S.A. reserves, argued in 1930 that "even while the responsible male times his visit home to coincide with the ploughing and seeding season, agriculture suffers. It allows of no preparatory cultivation nor does it enable him to take advantage of favourable rainfalls. It necessitates leaving to the women and to juniors the major part of the work. There can be no organised system of working. The standard of agriculture, therefore, is low and there can be no development" 2

It would seem therefore that the net effect of migration is to benefit the total community of the sending country. For although agricultural output may have fallen as a result of the migration, the earnings of the migrants more than compensate for this. If this were not so, then surely the migration would not have taken place.

However, although the migration leads to a greater gross national product it may, and in some cases almost certainly does, have a secondary effect of redistributing this income in such a way that some of those left behind are actually worse off than they would have been if there had been no migration. For if everybody stayed at home the food which the able bodied men produced would be used not only to feed themselves, their wives and children but would also be given to the old and crippled.

1 I. Schapera, Migrant Labour and Tribal Life (0.U.P., London, 1947) p. 164.

2 Germond, cited in Union of South Africa, Native Economic Commission 1930-32, p. 213 . 
But where migration exists not only may the workers spend a relatively higher proportion of his earnings on himself than he would in the country, but such money as he does send home may be used to feed and clothe a tighter family circle than previously. What little evidence there is suggests that the extent to which income distribution has changed as a result of migration has varied from place to place. There is not yet, as far av we are aware, any detailed investigation into any of the sending countries as to whether or not labour migration affected the income distribution within that country in such a way that some people are, in the short run, actually poorer off than they would have been if there was no migration.

(c) Long-run Effects on Capital Accumulation

The argument thus far is fairly straightforward. Men go off to the mines because by so doing they can improve their material position. Seen from a macro perspective there is a transfer of labour out of the agricultural sector into mining; resources are allocated more efficiently and output increases. The sending community as a whole (including migrants) benefits al though there may be redistribution of income which leaves some worse off. All this is in the short run. In the longer run, however, the argument is by no means so clear. The problem arises when one considers the impact of a national boundary between the migrant's home and his place of work and also the capacity of an economy, within national boundaries, to generate jobs and incomes. Ultimately this capacity to generate employment at a "reasonable" standard of living depends upon the capital accumulated in that society both in the form of material goods such as roads, dams and factories as well as in the form of appropriate "know-how" or responsiveness imbedded in people through education, experience and the social-structure. What then is the long term impact of a migrant labour system on the process of capital formation, and hence capacity to generate development within the sending country? 
Consider first the physical capital. There are a number of possibilities. The migrant mine worker from lesotho, for example, may use more; the same, or less of his earnings for maintaining and improving his land and livestock than he would have $d$ ne if he had remained a full time farmer. His government too may get more, less, or the same amount of taxes from the migrant that it would have got from the same fulltime farmer. But even if the migrant saves more than he would have done as a full-time farmer what of his ability to convert ${ }^{1}$ these savings into productive investment? From a theoretical point of view it would seem that, depending on the circumstances, oscillating migration could have the effect either of increasing or decreasing the rate of internal capital accumulation.

But there might even be situations where the impact of migration was to cause a disaccumulation (or negative rate of accumulation) of capital in the sending country. Suppose for example migrants used their land as a base on which to house their families and from which to extract what produce they could without putting back into the soil that which was necessary to prevent its destruction, through erosion, leeching of vital elements, etc. It is possible that as a result of migration the agricultural potential of a society may actually decline over time if the soil itself is allowed to run down and if the society changes in such a way that both in terms of social structure and in terms of individual know-how the community is less able to produce, with given resources, what once it could. We are not arguing that where actual agricultural output falls there is necessarily disaccumulation of capital; for the decline in output may be due simply to the fact that comparative advantage lies in producing less food and more of something else. What we are concerned about is the potential or capacity of that society to produce. food and provide employment if the men chose to go back to the land.

I I am indebted to Alex Petersen a member of the seminar group referred to in the first f.n. for his use of the concept of "convertibility" in discussion of an earlier draft of this paper. 
Thus far we have been arguing on the implicit assumption that over time population remains constant. But this is not so; in most sending countries population is rising, usually at a very rapid rate. It is not possible to know whether a system of ascillating migration over several generations is itself a cause of rapid population growth in the sending country, but one can at least explore how such a system affects or biases the way in which the society responds to a rural population explosion.

Where urbanisation takes place partly in response to a push from the land, the towns and cities themselves become generators of income and employment, through a process of capital accumulation. This capital, both physical and human comes not only from personal savings and income tax but also from reinvested profits as well as taxes on such things as corporate profits, sales of goods and so on.

When urbanisation takes place where a pattern of oscillating migration is maintained it is unlikely that capital formation will be shaped in such a way as to provide jobs for wives, schools for children and infrastructure in townships (roads, sewerage, etc.) for the families of migrants in the way that it would have been had the migrants urbanised permanently and brought their families with them. The bias in the shape of capital formation is, in the absence of an interventionist policy, likely to be even more pronounced where the migrants' rural homes are separated from the towns by a national frontier; for the effect of this boundary is to define the geographic limit beyond which those who control the economy of the receiving country feel no responsibility for the welfare of people living there. Hence there are few if any political pressures to use tax revenue, for example, to finance educational expenditure, say, on children living beyond the national boundary.

(d) Summary

In summary it would seem that a pattern of oscillating migration maintained over many years between urban and rural areas separated by some national boundary can have two contradictory 
effects. On the one hand it leads to higher incomes for the migrants whilst on the other it may simultaneously be slowing down if not actually reversing the rate of capital accumulation and hence capacity to generate employment and income in the sending country.

A pointer in this direction may be seen if one considers Lesotho where on the one hand there are 80,000 migrant miners each earning an average of nearly $R 600$ in South Africa whilst on the other there is a country which cannot even begin to feed itself although it was once, at the turn of the century, an exporter of food. Nor is it able to provide employment for all its citizens half of whose total male labour force is estimated to work on the mines and farms of the Republic of South Africa. It is estimated that the present rate of increase of the labour force in Lesotho is probably in the region of 6,000 a year of whom less than one-tenth will find employment in the country. ${ }^{1}$ In other words, after a hundred years of spectacular economic growth in South Africa in which Basotho have participated fully as diamond diggers, gold miners, farm labourers etc., Lesotho now finds itself with no rights of access to most of the accumulated capital which her citizens helped to form. Less than 10 per cent of her labour force is in paid employment inside the country and nearly half outside. There is no prospect of providing jobs either for those working outside the country or for the growing population. At the same time Lesotho is not considered as having any right to participate in decisions concerning employment outside her boundaries. When, for example, it was decided at the end of 1972 that the diamond mines in Kimberley should move away from a migrant system, close the compounds, and stabilise the labour force in family housing it was also decided that jobs would be

$I$ M. Wilson and L. Thompson (eds.) op.cit. 
given to local Africans only. And so although no individual migrant who wishes to continue working is being sacked he is not being allowed to settle nor bring his family to join him. The net result is that Lesotho which has for over 100 years been sending men to the diamond fields now finds that this area of employment is gradually being closed as the migrant system is phased out.

It would of course be a mistake to assume that a migrat system is the only cause of a country's inability to generate jobs for all its citizens. One need look no further than Southern Rhodesia which has for years received migrants and controlled its own capital accumulation to see that the causes of growing unemployment are more complex. But in analysing the long term consequences of a migrant labour system it is equally important not to ignore the way in which, over time, it can bias the formation of capital and actually reduce the capacity of a sending country to generate income and employment.

Such a process however is not inevitable. Although it seems likely that the impact of migration as sketched above for Lesotho has been similar in the other countries sending labour to South Africa we do not yet know enough, particularly about Mozambique and Malawi, to be able to say much about the capacity of those economies to generate employment. Malawi's apparent ability to defy the laws of economic gravity by abruptly cutting off the flow of tens of thousands of workers to the mines and absorb them in the local economy still requires detailed investigation and explanation. Could Mozambique which has been sending men for a longer period of time do the same thing?

We do not know the answers but we do know that the patterns of migration and capital accumulation that have emerged in Southerm Africa are not the only possibilities.

C. Oonclusion: Reducing the Dependence of Emigration Countries

As we turn now to look at the future let us examine what steps could be taken to reduce the dependence on the South African 
economy of the surrounding countries. What can be done by those countries which send migrant workers to South Africa to generate jobs for them at home? We would not pretend to attempt a full answer to this question but shall seek in this paper simply to explore one or two of the more immediate possibilities. One relates to industrial decentralisation; the other to correcting the bias in capital accumulation.

(a) Industrial decentralisation

The problem of industrial development in any one of the countries sending labour to South Africa cannot be tackled in isolation without taking cognizance of the fact that these countries have over time become peripheral areas to the nuclear core of South Africa's industrial centres. "It is for this reason", writes Percy Selwyn" "that development of industries in peripheral countries becomes an issue of such urgency; they see in the building up of growth centres associated with industrialisation an important means for countering the forces making for polarization in the region. But equally they may find the development of industries extremely difficult and the price which they have to pay for them very high." And in Southern Africa the peripheral former High Commission Territories have indeed found it impossible so far to generate an internal development to counteract the forces of polarization in such a way as to reduce their dependence on South Africa for employment.

There are numerous reasons why Botswana, Lesotho and Swaziland should find industrialisation so difficult. "Basically," writes Selwyn," "they amount to the fact that labour costs, if at all lower, are not sufficiently low to compensate for the higher transfer costs and lack of external economies involved in a

\footnotetext{
1 selwyn op.cit.

2 selwyn op.cit. p.32.
} 
peripheral location." Indeed the nature of the peripheral countries' links, via oscillating labour migration, with the core area militates against these countries making full use of their comparative advantage of lower labour costs. For although the existence of underemployment implies that the shadow wage rate is likely to be low, the fact that thousands of men go to and return from jobs on the mines at wages relatively far higher makes it even more difficult to counter the upward pressure on the peripheral country's internal wage rate. Nor is this pressure eased by the fact that it is the core-area's mining companies which are most likely to explore and invest in the periphery. For they then tend to pay wages to workers in emigration countries at the same level as they pay to these countries workers in South African mines. Thus we find that the nature of the core-periphery pattern as it has emerged in Southern Africa produces a situation where a perfectly appropriate pressure for higher wages in the core has results which, seen from the perspective of develcpment within a peripheral country, are singularly inappropriate in that they weaken the possibility of industrialisation to counteract the forces of polarisation. Nor is it only industrialisation that is affected.

With his detailed knowledge of agriculture in Lesotho Chaim Helman points out that the recent rise in mine wages may serve to reduce rather than increase investment by migrants in their land. This is because eamings per unit of time are so much greater on the mines that crop production by comparison may seem hardly worthwhile to the migrants. ${ }^{1}$

Returning for a moment to the possibilities of industrialisation there is one further obstacle that must be noted. This relates to the ability and propensity of South Africa to hinder

1 Chaim Helman, personal communication. 
the establishment of industries in the peripheral countries which are seen as potentially competitive with those already established within the Republic. Obstructive action is particularly likely to occur where the potential competition is within the borders of the Republic itself. ${ }^{1}$ In other words firms establishing themselves in peripheral countries with a view to producing for the core (South African) market may well face difficulties that would not be raised if their intended market was confined to the peripheral country. But the local market itself is generally insufficient to support local entrepreneurs for, quite apart from its inherent smallness due to small national population and low incomes, it is reduced still further by virtue of the fact that households are able, via the migrants, to buy in the South African market which is already large enough to reap substantial economies of scale.

Industrial decentralisation from core to periphery has in fact been tried within South Africa itself. But the evidence thus far indicates that it has been unsuccessful in restructuring the geographic patterm of growth in such a way as to increase employment in peripheral areas (where the people are) to a faster rate of growth than in the core areas whither they are being draw. ${ }^{2}$ The propects of industrial decentralisation are likely to be even dimmer in those peripheral areas which lie across a national boundary. Although the emigration countries have certain powers (e.g. to protect local industry or to negotiate foreign loans) ${ }^{3}$ not available to peripheries such as the

1 For example, a scheme to assemble motor cars in Lesotho was halted after pressure from Pretoria, Financial Mail (7.4.1972).

2 R. T. Bell, Industrial Decentralization in South Africa $(0 . U . P .$, Cape Town, 1973). See also Wilson, Migrant Labour op.cit. pp. $205^{\circ}$ ff. for discussion of some of the evidence.

3 See W. Henderson, "Independent Botswana: A Reappraisal of Foreign Policy Options", African Affairs, 1974. 
Ciskei, within the frontier of the core there is likely to be less political will on the part of the core (i.e. Pretoria) to encourage and pay for industrial growth in areas "beyond the fringe".

The analysis thus far has been concerned implicitly with such peripheral countries as Botswana, Lesotho and Swaziland. Does the argument hold true for Malawi and Mozambique? Far more empirical work needs to be done before one can answer this question but there are one or two points that can be noted immediately. First as regards Malawi it is possible that some of the links reinforcing its peripheral status are less strong than in the case of Lesotho. The very fact that South African producers are further away may make indigenous job creation more possible. But Malawi too is subject to the constraint of a small market. Turning briefly to Mozambique we note that, whilst on the one hand it has sent more men to the mines over a longer period of time than any other peripheral country, it is also the one that has developed a subsidiary core of its own. The growth of Lourenco Marques as a harbour town and the revenue from railway services are themselves directly due to the fact that Mozambique alone of the labour exporting countries demanded something from South Africa in return for a guaranteed supply of labour. ${ }^{1}$

Although often denounced as a bartering of human beings by imperial Portugal, the principle of labour-supplying areas negotiating for better terms than they would otherwise get is one that needs reconsideration and reformulation by countries now loosed from imperialist shackles and free to organise for their own well-being.

\section{(b) Correcting One-sided Capital Accumulation}

Industrial decentralisation is very diffialt. But the possibilities of development, both industrial and agricultural; could be greatly enhanced if somehow the labour link between

1 James Duffy, Portuguese Africa (H.U.P., Cambridge Mass., 1959) p.I70. 
peripheries and the core could be used to harness the resources now accruing to the core in such a way as to benefit the peripheries. The basis for negotiating a different shape to the growth of the Southerm African economy arises not only from the existing capital accumulation benefits which the Republic of South Africa derives from labour supplied by peripheral countries but also from the historic benefits derived from oscillating migrations in previous decades. A pointer to these benefits may be seen when one considers the following table 6 which shows the approximate number of man years invested by different countries in the gold and coal mines of South Africa since the Second World War.

\section{TABLE 6}

Approximate number of man years (black workers only) invested in mines, members of the Chamber of Mines, 1945 - 1974

A rea of Origin

$$
\text { No. of Man Years }
$$

$\%$

\begin{tabular}{rr}
3.6 & 34 \\
3.0 & 28 \\
2.0 & 19 \\
1.6 & 15 \\
0.4 & 4 \\
0.2 & 2 \\
10.7 & 100 \\
\hline
\end{tabular}

South Africa (mainly

Ciskei and Transkei)

Mozambique

"Tropical" (mainly

Malawi)

Leso tho

Botswana

Swaziland

Total

Source: W.N.I.A. Annual Reports.

Notes: 1. Figures do not add up exactly due to rounding

2. These figures refer to all large gold mines, coal mines of the Transvaal and to one or two others (e.g. Lohnro Platinum) but not to most other mines such as diamonds and copper.

3. The figures added up are of numbers employed at the 31st December each year. For the purposes of this table, we assume these to be constant throughout the year. 


\section{$-54-$}

Thus we see that over the thirty years 1945-1974 the number of man-years worked by black miners was approximately 10.7 million. In gold mines alone the totals were $10.3 \mathrm{~m}$. black and $1.3 \mathrm{~m}$. white man years. 1

How one decides the precise share of output which should accrue to a particular group of workers lies in the realms of theory far beyond the scope of this paper. Nevertheless it is a central theme of our argument that much of the surplus generated by economic growth cannot be said to be the sole property of any one factor as it is the fruit of joint product. Thus taxation on company profits, for example, is taken by the state on behalf of the people as a "social dividend" when due allowance has been made for payment in the form of interest, dividends, wages, or salaries to the various factors of production.

This principle is generally acceptable where the community producing the wealth lives within a single nation state; but it is not so widely accepted when part of the community lives outside the political boundary. Yet surely both logic and justice point to the imperative of extending the principle of distributing the social dividend at least as widely as the "labour catchment area" of any economy. Do not Mozambique, Lesotho, and the other countries which have invested 7.1 million man years in the South African mines since 1945 (to say nothing of the millions of man years in the sixty years before that) have some legitimate claim on the resources of the South African economy? The visible historic ties that bind these countries together in a common economy should surely serve to weave a less visible but equally binding web of mutual responsibility and sharing.

\section{(c) Areas of Negotiation}

If this view should become more generally acceptable as the basis on which to negotiate a structure of growth that was less biassed in favour of the core, along what lines should the peripheral countries bargain? There are, we suggest, two main areas

${ }^{I}$ Chamber of Mines Annual Reports. 
of negotation. The first relates to social dividends. In 1963 the combined Gross Domestic Product of Mozambique, Malawi, Botswana, Lesotho and Swaziland was $\$ 1,363$ million whilst in the year ending 31 March 1964 the tax revenue accruing to the South African government from the gold mines alone was $\$ 170$ million, i.e. no less than 12 per cent of the total G.D.P. of the five countries most involved in supplying labour to the mines. In 1967 when Lesotho supplied 60,000 men (16 per cent of the total) to the mines and her G.D.P. was R49m., South Africa's tax revenue directly from the gold mines was more than double that figure. (RI28 m. for the year ending 31.3.1968). By 1974 tax revenue from gold for the calendar year was estimated to be R8ll million. ${ }^{1}$

So great is the difference in capacity between the core and the countries on the periphery to generate income that even a small share of the tax revenue from sectors to which labour is supplied would alter significantly the ability of these countries to build an economic infrastructure.

The second area of negotiation lies in the field of markets. Let us illustrate the possibilities with a specific example. Suppose that Lesotho negotiated a guarantee to the effect that for every thousand Lesotho migrants employed on the mines in a given year South Africa would purchase a certain quantity of vegetables produced in Lesotho. Suppose further that, in addition to guaranteeing a market, the core area also agreed to provide the necessary funds for investment either from a share of tax revenue or from retained mining house profits - one would then find that two of the most critical barriers to development ( $v i z$. funds for investment and a market in which to sell the final product) had been overcome. In other words what we are suggesting is that countries that have been developed as peripheral areas have the potential to use the core country's need of their labour as an important asset in bargaining for a less lop-sided shape to the emerging pattern of growth in the economy of Southern Africa. The relative strength of such bargaining power will, of course, depend on the extent to which the peripheral areas are able to

I United Nations Yearbook of National Accounts Statistics 1972 Vol. III G.D.P. per capita in the various countries in 1963 was as follows:

Botswana $\$ 82$

Lesotho $\$ 64$

Swaxiland \$216

Malawi $\$ 42$
Mozambique $\$ 152$

Southerm Rhodesia $\$ 219$

South Africa (including

Namibia) $\$ 513$ 
act together. But it should also be noted that not all the claims for which they could negotiate would necessarily cost South Africa a great deal. Guaranteeing Botswana, for example, a market for a certain amount of a labour-intensive product could be enormously important in enlarging Botswana's capacity to generate employment and income but could be relatively costless to South Africa, particularly if the overall economy, including demand, was expanding.

The difficulty of such a policy is that it would serve to forgoe yet another structural link between South Africa and the peripheral countries at a time when the latter might wish, for political reasons, to break all ties with the former. But the option of breaking all links and turning its back on South Africa does not exist for every country on the periphery. The facts of life facing Lesotho are such that for the forseeable future it must send migrants abroad or starve. Malawi on the other hand has, in the short mun at least, been able to halt all recruiting and absorb the potential migrants locally. For Mozambique the options remain more open. One possible policy being discussed before independence in June 1975 was that the Frelimo government would allow existing migrants to continue working on the mines for as many contracts as they wished but that recruiting of new men would be banned. This is a policy of gradually severing the labour link. We know too little about the potential dynamics of development within an independent Mozambique to be able to make any predictions as to the likely policies and possible consequences of action regarding supplies of labour to South Africa. But we do know that for those countries which do decide to continue allowing men to migrate to the Republic of South Africa some assessment is needed as to the prospects for their employment.

(d) The Future of Migration for Employment

Predictions for the gold mining industry have been spectacularly wrong on many occasions in South African history. So it is with a due sense of trepidation that one attempts any forecasts regarding the future pattern of employment. However, 
a few tentative projections have been made. McDowall in his 1973 study of "Basotho Labour in South African Mines" concludes that "the signs ..... point to a reduction in the (South African) demand for Basotho labour, and the reduction could be expected to start in perhaps 3-5 years, and begin to bite in 10-12 years."1

Much depends, of course, on the future price of gold and on the general rate of growth of the South African economy as a whole. Looking at past trends one sees both in Southerm Rhodesia and in South Africa that employment opportunities for foreign black workers in agriculture have declined, due partly to such factors as natural population growth and mechanisation. Both countries at the beginning of the 1960's adopted policies of discouraging foreign migrants in specific sectors. But in South Africa the expansion of the mining and manufacturing sectors during the 1960's, combined with the wage gap between the two, led to an increasing demand by the mines for foreign labour. Whilst numbers from Botswana, Swaziland and Mozambique remained fairly constant the number of mine-workers from Lesotho and the Tropical areas increased from 134000 in 1960 to 215,000 in 1973. To what extent South Africa will be willing to continue employing 500,000 or more foreign workers as she has during the first half of the 1970's is impossible to forecast. The fact that the mines, notably gold, are actively seeking to reduce their proportion of non-South African blacks in the labour force and that they now have the capacity, because of the gold price rise, to raise wages to a level that could compete with the manufacturing sector does suggest that employment opportunities

1 McDowall op.cit. 
in the mines for foreign workers as a whole may have reached a peak in 1973 and be now in a state of decline. However, this does not necessarily imply either that employment opportunities in the mines for workers from particular countries will decline nor that jobs for foreign workers in the South African economy as a whole will become fewer.

Lesotho's access to the mines does not depend only on what happens within the Republic but also on whether or not Malawi decides to allow her citizens to work in South Africa. If she does not, then employment opportunities on the mines for Basotho are much less likely to decline. But even if Malawi or Mozambique do not cut off supplies permanently whilst gold mining begins to contract, it is possible that the decline in jobs for foreigners in this sector will be matched by new openings elsewhere in the economy. The expansion of mining other than gold may require more labour than can be attracted from within the borders of the Republic. It is conceivable that the pressure on the agricultural sector, as mining and manufacturing become more aggressive in pushing for the removal of restrictions that bind labourers to the white farms, will be such as to cause them to seek alternative, foreign, sources of labour, particularly for their seasonal requirements. As the Argentine sugar plantations draw on Bolivian cane cutters, or as North American market-gardeners fly in Jamaican workers, so too could the Natal cane growers draw on Lesotho, or the fruit farmers of the Westem Cape fly seasonal workers from Malawi - assuming of course that these countries were willing to allow their citizens to work in South Africa.

But recruiting through official channels is not the only possibility. The history of labour flows between Mexico and the United States particularly since the termination of the bracero programme in 1965 points to the extent to which illegal migration takes place even across well-patrolled borders. 
Even if decisions were made either by the South African govermmentor by one or more of the limitrophe countries to halt recruiting for work in the Republic of South Africa, it is highly probable that considerable numbers of "illegal aliens" would make their way across the frontiers. ". It is likely too that most of them would go first into agriculture where policing of the labour force is most difficult.

But all this is speculation. The labour market in Southerm Africa is in a greater state of flux than it has been since the discovery of minerals a century ago. What happens in the future depends on such a large number of variables and independent decision makers that it is impossible to predict events with any certainty. Some trends are visible but it is too early to tell whether the dividing line in Southern Africa between rich and poor, full employment and under-employment, is going to shift from the boundary of skin colour to that of the nation state. It is possible that the fundamental inequality in a region which has developed on a single economy, will emerge as that of a wealthy core (including some blacks) absolving itself of all responsibility for peripheral areas that are politically independent yet economically impoverished despite their active participation in a hundred years of spectacular economic growth. Whether or not the regional inequalities built into Southern Africa dring the past œntury will get better rather than even worse depends, in large measure, on the extent to which the various countries are able and willing to negotiate a differet shape to the pattern of growth. It is not inevitable, though without creative intervention quite possible, that the trends of the past will continue into the future.

1 Existence of illegal aliens was being reported in the South African press during 1975 e.g. Aida Parker S.A. Financial Gazette (1975). 